\title{
Surgical Management of Impacted Lower Second Molars: A Comprehensive Review
}

\author{
Diane Isabel Selvido $^{10}$ Nattharin Wongsirichat ${ }^{2(0)}$ Pratanporn Arirachakaran $^{10}$ Dinesh Rokaya ${ }^{10}$ \\ Natthamet Wongsirichat ${ }^{10}$
}

${ }^{1}$ Clinical Science Department, International College of Dentistry, Walailak University, Bangkok, Thailand

2 Department of Preventive Dentistry, Division of Orthodontics, Faculty of Dentistry, Khon Kaen University, Khon Kaen, Thailand

\begin{abstract}
Address for correspondence Natthamet Wongsirichat, BSc, DDS, International College of Dentistry, Walailak University, 73 PhraRam 6 Road, Phaya Thai District, Bangkok 10400, Thailand (e-mail: natthamet.wo@mail.wu.ac.th).
\end{abstract}

Eur J Dent 2022;16:465-477.
Abstract
Keywords
- impacted lower second molars
- molar impaction
- lower third molars
- surgical uprighting
- surgery
- extraction
- impaction
- second molars

Impacted lower second molars (ILM2) are rarely reported in the literature, but various studies have been done for its treatment. Apart from solely orthodontic approaches, different surgical management techniques were reported to have successful outcomes. Surgical intervention of ILM2 can help expose the tooth for further orthodontic purposes, simplifying complex treatment methods, and reducing treatment time. This review illustrates the comprehensive evaluation and updated methods of surgical uprighting, repositioning, and transplantation of ILM2 with future directions for better understanding and treatment planning in the clinical setting. The successful outcome of surgical intervention depends on case selection, root development of ILM2, careful surgical manipulation, and adherence to sound biological principles.

\section{Introduction}

The nature of impaction of second molars has been observed to be an outcome of inadequate skeletal development to permit normal and undisturbed eruption. ${ }^{1,2}$ The management of this occurrence has been challenging for orthodontists and oral and maxillofacial surgeons because of the technique-sensitive treatment planning, varying prognosis, and limited access to the tooth. ${ }^{3,4}$ Objectives of imposing the tooth to be placed and positioned in its ideal position in the dentition are to avoid dental caries and possible inflammation of the periodontium in proximity to the distal of the first molar to inhibit arch discrepancies that may lead to instabilities. ${ }^{3}$ Additionally, mastication muscles can be functionally affected by impacted second molars. ${ }^{5}$

Second molar impaction is rarely reported in the literature, mainly because of its sporadic occurrence. ${ }^{2}$ Together with first molars, it has a prevalence of 0.01 to $0.8 \%{ }^{6,7}$
Moreover, among patients undergoing orthodontic treatment, the prevalence of this impaction was reported to range between 2 and 3\%. ${ }^{2,8}$ This type of impaction is frequent in the mandible compared with the maxilla and is described as unilaterally occurring in the dental arch. In addition, second molar impaction leans toward predilection in males compared with females, and is usually mesially inclined. ${ }^{8-10}$

Management of impacted second molars has been discussed in the literature to be employing surgical or nonsurgical approaches. ${ }^{5}$ As per Boynton and Lieblich, there is a consensus that conventional nonsurgical treatment, even if noninvasive, requires a long treatment period to complete. In addition, considerations like patient's adherence to proper oral hygiene and protocols and consistent orthodontic visits, especially in severe cases, are emphasized in the nonsurgical approach. ${ }^{11}$ The surgical approach can be an optimum solution to some of the clinical dilemmas being faced by nonsurgical methodologies. ${ }^{12}$ According to Anderson et al, surgical

(C) 2022. The Author(s).

This is an open access article published by Thieme under the terms of the Creative Commons Attribution License, permitting unrestricted use, distribution, and reproduction so long as the original work is properly cited. (https://creativecommons.org/licenses/by/4.0/)

Thieme Medical and Scientific Publishers Pvt. Ltd., A-12, 2nd Floor, Sector 2, Noida-201301 UP, India 
manipulation of impacted molars helps access the impacted tooth to bond with orthodontic brackets or buttons, assists in simplifying complicated treatment methods, and aids in reduction of treatment timelines. ${ }^{3}$ The specific management varies from case to case and demands special attention since an impacted mandibular second molar can cause caries, periodontal problems, and resorption of the roots of the distal root of the first molar. ${ }^{13-15}$ Several authors agree that surgery is an effective strategy in accessing, uprighting, and positioning impacted second molars. ${ }^{5,16,17}$ These methods are deemed necessary since the result of manipulating impacted second molars, in general, can be unpredictable, and depends on timely detection and treatment. ${ }^{7}$

The literature on ILM2 can be divided into two entities: surgical and nonsurgical. Although numerous case studies and retrospective studies are available about the surgical aspect, there has not been a review done exclusively about the various surgical techniques. In line with that, this review aims to illustrate a comprehensive account of the surgical management of ILM2 used in clinical settings.

\section{Methods}

Electronic databases were utilized, such as Scopus, PubMed, PubMed Central, and EBSCO using associated keywords. The computerized search comprises case reports, literature reviews, clinical trials, retrospective studies related to mandibular or lower second molar impaction management, and surgical treatment modalities. All related topics searched were "surgical management" plus keywords such as mandibular or lower second impacted molars, surgical impaction managements, surgical uprighting, surgical repositioning, transplantation, autotransplantation, and other related subjects about lower second molar impactions. Publications in the English language were collected. Most of the literatures gathered in the indices were peer-reviewed articles related to impacted mandibular second molars, with 18 case reports and 6 retrospective studies.

\section{Initial Assessments}

Similar to nonsurgical methods, a panoramic radiograph has been the imaging of choice of many authors in their respective reports. Panoramic radiographic imaging should be in conjunction with clinical examination to accurately identify the occurrence of impacted second molars and for postoperative assessment, especially when surgical intervention is considered necessary. Retrospective studies have relied upon these panoramic radiographs in ILM2. ${ }^{14,18}$ Some studies also used periapical radiographs for a more detailed viewpoint. ${ }^{19,20}$

According to Kravitz et al, a panoramic image can predict an upcoming ILM2 in a preadolescent patient when the third molar tooth follicles are placed on top of the incomplete second molar. ${ }^{4}$ In surgical uprighting or repositioning and transplantation, numerous authors have synonymously noted the ideal age of treatment to be between 11 and 15 years old, with one-half to two-thirds of root formation. These parameters are best identified by panoramic imaging. $2,4,10,12$
Another assessment being used today is cone beam computerized tomography [CBCT] which can identify obstructions in the eruption pathway. This particular evaluation was helpful in a report presented by Lorente et $\mathrm{al}^{21}$ in a maxillary impacted second molar. CBCT can easily distinguish molar infraocclusions, molar angulations, and anomalies such as dilacerations that can deter the eruption of second impacted molars. Particularly, in the case of the ILM2, it serves as a valuable tool. ${ }^{22}$ Since this method can identify any possible obstructions preventing eruptions of the said teeth in many planes of view, its utilization can assist significantly in maxillary and mandibular second molar impaction cases.

Surgical Exposure of the Impacted Lower Second Molars A careful assessment for surgical exposure of the ILM2 includes clinical and radiographic means. If the clinician observes that the ILM2 are not erupting within 6 to 12 months, a radiographic assessment can be performed to validate if there is an aberration or hindrance in the physiologic eruption pattern..$^{20,23,24}$ On the condition that the tooth is situated deep in its position, only surgical exposure may be indicated, and placing bonding attachments is unfeasible because of its difficult isolation. ${ }^{25}$

Exposure is usually the first step in every surgical approach. It can be combined with other methods of uprighting second molars, including surgical luxation, surgical uprighting with miniscrews/miniplates, and orthodontic-assisted uprighting. ${ }^{14}$

Kenrad et $\mathrm{al}^{23}$ reported that surgical exposure for ILM2 had solved the problem regarding crown follicle retention, which causes the impacted second molar to not erupt at the expected range of time. They also stated that surgical exposure had the highest success rate of $90 \%$ among all surgical methods performed as spontaneous eruption was achieved. According to Magnusson and Kjellberg, ${ }^{26}$ surgical exposure is the most effective treatment for impacted or retained second mandibular molars, with a 71\% success rate for maxillary and mandibular second molars, particularly gaining positive results with a total of seven impacted second mandibular molars. Both maxillary and mandibular impacted second molars were discussed in their study, but the latter was used in the majority of the surgical exposure group that demonstrated favorable outcomes compared with other surgical approaches of impacted or retained impactions. ${ }^{26}$ In a recent study by Abate et al, ${ }^{27}$ operculectomy, a procedure where the clinician eliminates the soft tissue covering of an impacted or partially erupted tooth, which also resembles surgical exposure, successfully stimulated physiologic eruption when performed on 30 counts of ILM2. Their study also advised that vertically positioned and mesioangularly inclined second impacted molars benefit more from the case selection of this procedure.

The number of ILM2 in the studies mentioned earlier is very few, so further studies are needed. Nevertheless, overall outcomes have shown that surgical exposure is the easiest management that can be combined with other methods of surgical uprighting because of the simplicity of the procedure. A summary of retrospective studies regarding second 
Table 1 Second mandibular molars utilizing surgical exposure on retrospective studies

\begin{tabular}{|l|l|l|l|}
\hline Author & Age group & $\begin{array}{l}\text { No. of second impacted } \\
\text { mandibular molars }\end{array}$ & Outcomes \\
\hline${\text { Kenrad et } \text { al }^{23}}^{\text {Magnusson and Kjellberg }}{ }^{26}$ & $\begin{array}{l}11 \text { years 2 months to } \\
19 \text { years } 8 \text { months }\end{array}$ & 10 & $\begin{array}{l}\text { Spontaneous eruption } \\
\text { achieved }\end{array}$ \\
\hline Abate et al 2 $^{27}$ & $\begin{array}{l}\text { Mean age } 14.8 \pm 1.3 \\
\text { years }\end{array}$ & $\begin{array}{l}7+1 \text { primary retained } \\
\text { tooth }\end{array}$ & $\begin{array}{l}\text { Most successful treatment } \\
\text { outcome, } 71 \%\end{array}$ \\
\hline
\end{tabular}

Table 2 Case reports on surgical exposure of second mandibular molars

\begin{tabular}{|l|l|l|l|l|l|l|}
\hline Author & Year & $\begin{array}{l}\text { Second } \\
\text { molars }\end{array}$ & Age, gender & $\begin{array}{l}\text { Time of } \\
\text { uprighting }\end{array}$ & $\begin{array}{l}\text { Adjacent third molar } \\
\text { status }\end{array}$ & Remarks \\
\hline Sawicka et al ${ }^{28}$ & 2007 & 37,47 & $\begin{array}{l}14 \text { years old, } \\
\text { female }\end{array}$ & 5 months & $\begin{array}{l}\text { Third molar was removed } \\
\text { after uprighting }\end{array}$ & $\begin{array}{l}\text { Orthodontically } \\
\text { assisted }\end{array}$ \\
\hline Manosudprasit et al ${ }^{25}$ & 2013 & 37,47 & $\begin{array}{l}17 \text { years old, } \\
\text { female }\end{array}$ & 13 months & $\begin{array}{l}\text { Third molar was removed } \\
\text { before uprighting }\end{array}$ & $\begin{array}{l}\text { Orthodontically } \\
\text { assisted }\end{array}$ \\
\hline
\end{tabular}

mandibular molars utilizing surgical exposure is presented in - Table 1.

Second molar impaction is a rare occurrence, as previously mentioned. Thus, there is a lack of available studies about ILM2 in the literature worldwide. However, there are a few studies supporting that surgical exposure is the simplest modality to accommodate ILM2 eruption. Studies suggest that surgical exposure is more convenient and easier with orthodontic correction. Sawicka et $\mathrm{al}^{28}$ reported that bilateral ILM2s were uprighted after surgical exposure and orthodontic uprighting. A study by Manosudprasit et $\mathrm{al}^{25}$ also benefited from this method. Surgical exposure studies are shown in - Table 2.

Wound healing problems would be a limitation of this procedure as impaired wound healing would cause further infection of the exposed site and incompliance. ${ }^{29}$ Oral hygiene should also be reinforced for optimal healing of the exposed site.

\section{Surgical Positioning/Uprighting by Luxation}

The decision to perform surgical uprighting should be made when all the conservative options for treatment are deemed to be unsuitable. ${ }^{30}$ Many clinical implications are expected when surgical uprighting by luxation is involved, but it is still preferred over orthodontic extrusion since such a procedure was declared to have disadvantages. Surgical uprighting may prevent abnormality in the occlusal plane from the impacted tooth loss, supraeruption of the opposing tooth, and reduces the possibility of periodontal and prosthodontic problems in the future. ${ }^{31}$ The results of this procedure were known to have a favorable prognosis, particularly when incomplete root formation is present. ${ }^{4,18}$

Mindful surgical manipulation with minimal likelihood of injury to the cementum and periodontal ligament is advantageous in efficient bone regeneration. Following the concept of primary closure, osteogenic activity can be initiated, possibly developing mature bone on the crestal region. Thus, the importance of atraumatic and conservative uprighting and repositioning should be emphasized. ${ }^{32}$

The process of luxating to an ideal uprighted position also has clinical restrictions when it comes to angulation. Pogrel indicated that the second molar should be slowly uprighted not beyond 90 degrees as this can lead to detrimental pulpal status postoperatively. ${ }^{35}$ Cho et al suggested that the inclination angle between the first and second molars should be 75 degrees. ${ }^{33}$ Both studies are congruent to each other as they indicate that exertion to angular limits would instigate behavior similar to uncontrolled transplantation that will negatively affect the tooth.

Peskin and Graber ${ }^{34}$ advised the use of gelfoam, an absorbable gelatin sponge, placed around the prepared area in the event that the tooth is mobile after the operation. Similarly, in a retrospective cohort study by Caminiti et al, ${ }^{14}$ they positioned a wedging sheet of surgicel to the mesial space to act as a stabilizer and a hemostatic agent on the luxated lower second molars. Another suggestion was from Dessner, where he instructed that the bone removed from the distal of the second molar prior to uprighting may be used as a wedge to the first molar to stabilize it. ${ }^{10}$ An autogenous bone has also been mentioned to fill areas devoid of bone for splinting purposes. $^{5,32}$ However, Boynton and Lieblich ${ }^{11}$ advocated that autogenous bone, bone grafts, and other adjuncts are not necessary to stabilize the repositioned second molar. All suggestions are acceptable for preventing mobility of the uprighted tooth, leading to optimal healing of periodontal tissues.

Timing is important, especially when the clinician uprights the lower second molar. Some authors did not mention the ideal ages when to upright an ILM2 but did elaborate on the optimum root formation stage, which is 
Table 3 Advised age and root development for surgical uprighting of second mandibular molars

\begin{tabular}{|l|l|l|}
\hline Author & Age & Root development \\
\hline Pogrel $^{35}$ & $11.7-17.9$ years old & $2 / 3$ root completed with open apices \\
\hline Dessner $^{10}$ & Not mentioned & $2 / 3$ of root formation \\
\hline Sawicka et al & $11-14$ years old & Incomplete root formation \\
\hline Kravitz et al $^{48}$ & $11-15$ years old & $1 / 2$ to $2 / 3$ root formation \\
\hline McAboy et al & Not mentioned & $1 / 3$ to $1 / 2$ of the final root length \\
\hline Boynton and Leiblich & 11 & $2 / 3$ of root formation \\
\hline
\end{tabular}

Table 4 Retrospective studies on surgical uprighting of impacted mandibular second molars

\begin{tabular}{|c|c|c|c|c|c|c|c|}
\hline Author & Year & Tooth \# & Sample size & Mean age & $\begin{array}{l}\text { Follow-up } \\
\text { periods }\end{array}$ & $\begin{array}{l}\text { Adjacent third } \\
\text { molar status }\end{array}$ & Outcomes \\
\hline Pogrel $^{35}$ & 1995 & 37,47 & 16 patients & 14.1 years & $\begin{array}{l}\text { Minimum of } \\
18 \text { months }\end{array}$ & $\begin{array}{l}4 \text { cases of third } \\
\text { molars were not } \\
\text { removed }\end{array}$ & $\begin{array}{l}\text { Optimum } \\
\text { stabilization was } \\
\text { achieved in } \\
\text { most cases } \\
\text { performed } \\
\text { with careful } \\
\text { bone reduction }\end{array}$ \\
\hline Padwa et al ${ }^{18}$ & 2017 & 37,47 & 16 patients & $13 \pm 1.1$ years & $\begin{array}{l}\text { Postoperative } \\
\text { radiographs } \\
\text { obtained } \\
2.4 \pm 1.4 \text { years } \\
\text { later }\end{array}$ & $\begin{array}{l}\text { Third molars } \\
\text { were removed } \\
\text { in } 50 \% \text { of } \\
\text { the patients }\end{array}$ & $\begin{array}{l}\text { Pulp obliteration, } \\
\text { periapical } \\
\text { radiolucency, } \\
\text { and root } \\
\text { resorption were } \\
\text { seen in } 31.6 \% \\
\text { of patients }\end{array}$ \\
\hline Caminiti et al $^{14}$ & 2020 & 37,47 & $\begin{array}{l}177 \text { patients } \\
\text { with } 260 \\
\text { mandibular } \\
\text { second molars }\end{array}$ & 14.8 years & 6 months & $\begin{array}{l}86.9 \%(266) \\
\text { of third } \\
\text { molars } \\
\text { removed }\end{array}$ & $\begin{array}{l}255 \text { out } \\
\text { of } 260 \text { second } \\
\text { molar teeth } \\
\text { were successfully } \\
\text { uprighted } \\
\text { from } 177 \text { patients }\end{array}$ \\
\hline
\end{tabular}

one-half to two-thirds root formation. ${ }^{4,5,10,11,35}$ The recommended age to start the treatment was 11 years old. ${ }^{4,11,28,35}$ Incomplete root formation leads to better prognosis and fewer complications, as open apices allow for ease of vascularization of the pulp complex. ${ }^{36}$ The suggested age and corresponding root development by different authors for surgical uprighting are presented in -Table 3.

While the presentation of the widely used surgical uprighting is safe and effective for second mandibular molars, it is important to note that case selection and proper knowledge of the second molar root development should be practiced thoroughly. ${ }^{23,28,37}$ Patient's cooperation and good oral hygiene are requirements for best possible results. The patient should see the orthodontist to proceed with their respective treatment plan after 1 to 2 weeks. ${ }^{4}$ A summary of the retrospective studies and case reports are shown in -Tables $\mathbf{4}$ and $\mathbf{5}$, respectively.

\section{Soft Tissue Management after Surgical Positioning/Uprighting}

There is no definite guideline on soft tissue handling after surgical manipulation of ILM2. It has been emphasized that

Table 5 Case reports on surgical uprighting of impacted mandibular second molars

\begin{tabular}{|l|l|l|l|l|l|l|}
\hline Author & Year & $\begin{array}{l}\text { Second } \\
\text { molars }\end{array}$ & Age, female & Follow-up & $\begin{array}{l}\text { Adjacent third } \\
\text { molar status }\end{array}$ & Outcomes \\
\hline $\begin{array}{l}\text { Shipper and } \\
\text { Thomadakis }\end{array}$ & 2003 & 37,47 & $\begin{array}{l}11 \text { years, } \\
\text { female }\end{array}$ & $\begin{array}{l}3 \text { months, } \\
6 \text { months, } \\
\text { until 3 years }\end{array}$ & $\begin{array}{l}\text { Third molars } \\
\text { removed }\end{array}$ & $\begin{array}{l}\text { \#37 normal after } 6 \text { months } \\
\text { the tooth was } \\
\text { endodontically treated } \\
\text { twice but eventually } \\
\text { healed after } 3 \text { years }\end{array}$ \\
\hline McAboy et al ${ }^{5}$ & 2003 & 47 & $\begin{array}{l}14 \text { years old, } \\
\text { female }\end{array}$ & Up to 3 years & $\begin{array}{l}\text { Third molar } \\
\text { removed }\end{array}$ & The tooth was vital \\
\hline
\end{tabular}


effective soft tissue management warrants the success of the overall treatment outcomes. However, according to Anderson et $\mathrm{al}^{3}{ }^{3}$ there is a shortage of studies because of time limitations. The clinician can then acquire careful tissue handling that is consistent with other surgical procedures performed in the lower arch.

Preferably, the uprighted tooth should be reduced on the occlusal surface to be slightly out of contact to prevent occlusal and soft tissue trauma. ${ }^{5}$ In a technical note by Anderson et al, ${ }^{3}$ they recommended flap repositioning and occlusal composite button placement in terms of soft tissue management. The flap repositioning is needed to minimize tissue trauma of the expected buccal flap created after the said modality. This procedure can be accomplished by doing conservative osteotomy from the marginal buccal bone of the repositioned ILM2 to the third molar extraction area. Once adequate bone removal is achieved, the flap will be approximated from the distal of the second molar then sutured to close.

An occlusal composite button is an added accessory which will raise the bite to keep the flap undisturbed, thereby promoting proper healing. The orthodontist can remove the button during their treatment time, 10 to 14 days after surgical manipulation. Indeed, this method will be difficult to achieve when the third molar is preserved. This method was stated to have advantages like preserving the keratinized buccal gingiva, preventing plaque accumulation, and avoiding hyperocclusion. ${ }^{3}$

The occurrence of pseudopockets can also be a major problem for the clinician since there is unpredictable soft tissue behavior after second mandibular molar uprighting. One possible technique to prevent periodontal problems is distal wedge surgery which can be performed in the area of the third lower molars to the second mandibular molar if removal of the third molar is indicated. In this procedure, a triangular incision is made with the apex of the incision located in the direction of the retromolar area and the base located in the distal part of the uprighted second molar. ${ }^{38}$ This technique is favorable for cases where the third lower molar is indicated to be extracted. Additionally, it facilitates healthy healing around the second lower molar tissues. This method was applied by Leechanavanichpan et $\mathrm{al}^{39}$ in 2019 , where impacted mandibular third molar was surgically removed with distal wedge incision, and it created positive periodontal clinical outcomes. The distal wedge technique is mostly used during odontectomy procedures and can be beneficial in second mandibular molar uprighting, preventing clinical attachment loss and plaque retention to the distal part of the molar.

Another soft tissue management method is covering the operated site with a periodontal dressing of choice that can be placed to splint the tooth for stabilization and avoid buccal tissue trauma. ${ }^{4}$ The dressing can also serve an additional purpose of inhibiting the soft tissue from slowly covering the crown of the uprighted tooth. ${ }^{14}$ Prevention of this adverse event is important as its removal can be tedious. In addition, problems such as inflammation of the gingiva and caries formation in the second molar are possible complications of this condition.
Irrigation of the exposed area is also advised postoperatively, using a syringe to prevent food debris accumulation on the area, making the site infection-free. ${ }^{20}$ Any other adjuncts for proper care of surgical sites are strongly recommended so that the tooth will not be indicated for subsequent extraction.

\section{Uprighting with Miniplate and Miniscrew Application}

Over the last decade, there have been increases in the number of case studies and reviews regarding miniplates and miniscrews in uprighting ILM2. ${ }^{40}$ These devices have been chosen for molar uprighting procedures with orthodontic appliances as they offer stability and anchorage during uprighting. ${ }^{41}$ Both anchorage devices were known to have special considerations and shortcomings.

Miniscrews provide optimal stability and the necessary force to move the tooth. They are conservative and inexpensive as well. However, the placement should be done by an experienced clinician, and the precision of placement should be supplemented by three-dimensional imaging for proper installation. ${ }^{42}$ In the mandible, special considerations are emphasized since it has a higher amount of cortical bone that correlates with the compromised stability of miniscrews. ${ }^{43}$ An interesting finding by Samrit et $\mathrm{al}^{44}$ revealed that the miniscrew application is predominantly successful in the maxilla than the mandible to a general extent. Nevertheless, many case studies report successful outcomes with uprighting using miniscrews in ILM2.

On the other hand, miniplates are stronger and sturdier than miniscrews, but are expensive. In addition, they require invasive surgery rendering them to be traumatizing. ${ }^{42}$

In general, both miniscrews and miniplates are efficient in retraction and distalization on both dental arches. ${ }^{41}$ However, there is less concern when it comes to placement with miniplates due to the fact that there is less risk of damaging vital structures. ${ }^{45}$

There are two types of miniscrew anchorage: direct anchorage, which involves mounting the miniscrew in the retromolar region; and indirect anchorage, in which placement is situated between the roots of the teeth. ${ }^{15}$ Of the two types, the direct anchorage was mentioned to be more favorable for immediate orthodontic loading. ${ }^{46}$ An example of direct anchorage is from a 2020 case study by Altieri et $\mathrm{al}^{16}$ who used a miniscrew anchorage drilling in the retromolar area along with orthodontic assistance to upright bilateral ILM2. Similarly, Giancotti et $\mathrm{al}^{47}$ in 2004 placed a 7mm-long miniscrew in the retromolar triangle to upright a left ILM2 in the same day, with $50 \mathrm{~g}$ of force applied by the elastics. Furthermore, from the same author, a $150 \mathrm{~g}$ was exerted for a right ILM2 after miniscrew installation on the same area as well. ${ }^{48}$ Hence, the force of 50 to $150 \mathrm{~g}$ can then be applied on ILM2 uprighting, with cautious manipulation.

In indirect anchorage, an example would be from a case series by Lee et $\mathrm{al}^{15}{ }^{15}$ where they placed the miniscrew in the buccal cortical bone between the first mandibular molar and second premolars. They used an open coiled spring to maximize the distalizing force to fully upright the ILM2 in its rightful position. Three of the cases presented were 
adolescents aged 12,13, and 16 years old, respectively. All of the cases reported success in uprighting via indirect anchorage with miniscrews, even in the case of a 13-year-old patient who did not undergo lower third molar removal. Therefore, miniscrews can be used even if third molar removal is not warranted.

Two miniscrews with slots placed carefully on the buccal alveolus between mandibular first molar and second premolar, and between second premolar and first premolar, can also be installed to increase retention, making the whole setup impervious to orthodontic forces. ${ }^{49}$ Compared with the case report by Lee et al, correction with added miniscrews took almost double the time as compared with one miniscrew with open coil springs. The cause of the prolonged time was possibly because some patients in this case series had dislodged miniscrews before the ILM2 got uprighted. Orthodontic biomechanics needed in the use of miniscrews, however, is beyond the scope of this review.

Complex uprighting with miniscrews is also an option, as with Celebi and colleagues ${ }^{50}$ approach on uprighting. The miniscrew was installed in the upper posterior alveolus area for maximum traction from the maxillary arch. Regardless of the location of the miniscrew, uprighting time is the same as the miniscrews placed in the mandibular arch.

Similarly, with miniscrews, miniplates should also be mounted by a clinician with proficient knowledge of the mandibular anatomy as proper flap reflection is required. ${ }^{51}$ It is usually performed by oral surgeons. Regardless of the invasiveness of the procedure, the chance of iatrogenic nerve impairment is less concerning. ${ }^{52}$ As it stands, there are no known fractures involving miniplates and their subsequent screws as they are known to be very rigid. ${ }^{42}$
Most miniplates in the mandible for molar uprighting are placed in the retromolar region, and they can be used for disimpacting deep ILM2. An instance is a clinical report by Tseng et $\mathrm{al}^{52}$ that utilized a four-hole L-shaped miniplate drilled by miniscrews in the buccal cortex near the retromolar area as an anchorage for orthodontic ILM2 uprighting. The case was corrected in 8 months. Miyahira et $a^{53}$ also had a case with a 12-year-old patient in which they used an Lshaped miniplate positioned distal to the ILM2. With the help of optimum orthodontic forces, an ILM2 was nearly uprighted for 3 months. This technique can be considered invasive, but in spite of the trauma it entails, outcomes have been reported to be acceptable.

In the studies mentioned, it is clear that miniscrews have been mostly utilized in ILM2 uprighting cases. Miniplates, however, with their limited studies, should not be concluded lightly. Sherwood et $\mathrm{al}^{51}$ claimed that miniplates are more stable than other anchorage devices. In contrast, several miniplates in the mandible in a study by Choi et al ${ }^{54}$ had failed, with a $7 \%$ failure rate. Thus, more studies are needed in this type of modality in ILM2 to determine the exact success rate of this procedure.

Case reports used to upright ILM2 with miniscrews and miniplates have shown that there is correction regardless of the age and degree of root development, as some of the patients already have fully developed second mandibular molar roots. The details are presented in - Table 6.

As per Giancotti et al, ${ }^{48}$ wound healing of the surgical site of miniscrew placement takes 10 to14 days. Miniplate healing, on the other hand, is assumed to be longer because of the expected swelling within 7 days post placement and within 7 days after removal. ${ }^{55}$ Flapless miniscrew placements have

Table 6 Summary of case reports utilizing miniscrews and miniplates for impacted second mandibular molar uprighting

\begin{tabular}{|c|c|c|c|c|c|c|}
\hline Author & Year & $\begin{array}{l}\text { Anchorage } \\
\text { device }\end{array}$ & $\begin{array}{l}\text { Tooth } \\
\text { number }\end{array}$ & Age, gender & $\begin{array}{l}\text { Time } \\
\text { uprighted }\end{array}$ & Adjacent third molar status \\
\hline Giancotti et al $^{47}$ & 2004 & Miniscrew & 37 & 27 years, male & 8 months & $\begin{array}{l}\text { Third molar removed before } \\
\text { uprighting }\end{array}$ \\
\hline Lee et $\mathrm{al}^{15}$ & 2007 & Miniscrew & $\begin{array}{l}47 \\
37 \\
47\end{array}$ & $\begin{array}{l}12 \text { years, female } \\
13 \text { years, female } \\
16 \text { years, male }\end{array}$ & $\begin{array}{l}5 \text { months } \\
5 \text { months } \\
2 \text { months }\end{array}$ & $\begin{array}{l}\text { Cases } 1 \text { and } 3 \text { opted for third } \\
\text { molar removal, while case } 2 \\
\text { uprighting accomplished with } \\
\text { adjacent third molar }\end{array}$ \\
\hline Nęcka et al ${ }^{46}$ & 2010 & Miniscrew & 47 & 15 years, male & 6 months & $\begin{array}{l}\text { Third molars removed before } \\
\text { uprighting }\end{array}$ \\
\hline Celebi et $a^{50}$ & 2011 & Miniscrew & 37 & 15 years old, male & 8 months & Third molar not removed \\
\hline Mah et $a^{49}$ & 2015 & $\begin{array}{l}\text { Miniscrews } \\
(2)\end{array}$ & $\begin{array}{l}37,47 \\
47 \\
37,47\end{array}$ & $\begin{array}{l}11 \text { years, female } \\
13 \text { years, female } \\
13 \text { years, male }\end{array}$ & $\begin{array}{l}9 \text { months } \\
13 \text { months } \\
12 \text { months }\end{array}$ & $\begin{array}{l}\text { Agenesis } \\
\text { Agenesis } \\
\text { Third molar extracted before } \\
\text { uprighting }\end{array}$ \\
\hline Altieri et al $^{16}$ & 2020 & Miniscrew & 37,47 & 12 years, female & 3 months & $\begin{array}{l}\text { Third molar extracted before } \\
\text { uprighting }\end{array}$ \\
\hline Lorente et $\mathrm{al}^{21}$ & 2021 & Miniscrew & 47 & 13 years, male & 4 months & Agenesis \\
\hline Tseng et $\mathrm{al}^{52}$ & 2008 & Miniplate & 37 & 19 years, female & 8 months & $\begin{array}{l}\text { Third molar extracted before } \\
\text { uprighting }\end{array}$ \\
\hline Miyahira et $a^{53}$ & 2008 & Miniplate & $\# 47$ & 12 years, male & 3 months & $\begin{array}{l}\text { Third molar extracted before } \\
\text { uprighting }\end{array}$ \\
\hline
\end{tabular}


higher success rates with reduced pain and discomfort than those performed with full-thickness flap surgery. In the case of miniplate installation, postoperative pain is experienced with or without flap operation. ${ }^{56}$ Patients were also known to be comfortable in the placement and removal of miniscrews, but in the case of miniplates are believed to be otherwise. $^{47,57}$ Nevertheless, best oral hygiene practices are advised since these are plaque-retentive fixtures. Patient cooperation is also key to avoid dislodgement and subsequent swallowing of the small components.

\section{Extraction of the Second Mandibular Molar}

The etiologic factors of ILM2 according to Kenrad et $\mathrm{al}^{23}$ are secondary retention, decreased space, and anomalous inclination. Gooris et $\mathrm{al}^{58}$ proposed the removal of these ILM2 as there is anticipation that the third molar will eventually erupt toward the extracted second molar's position. Interestingly, Orton-Gibbs et al asserted that third molars, even with severe angulation, can replace these ILM2 effectively after extraction. There is an immense risk as the space of the extracted site does not ensure the eruption of the third molar. ${ }^{59,60}$ Known cases of successful replacement were seen in the maxillary arch. ${ }^{61}$ However, in the mandibular arch, failed replacements were observed. ${ }^{62}$

Clinically, the option to extract the ILM2 is advised if uprighting/repositioning has been deemed impossible because of its detrimental position in the mandibular arch. ${ }^{63}$ While radiographically, there are factors to be considered to utilize extraction for effective replacements: proximity of the tooth follicle to the ILM2 roots, the minimal amount of tipping, and crown completion of the third mandibular molar bud. ${ }^{58}$

Another contributing indicator for ILM2 extraction is the patient's age, wherein the more advanced the age, the possibility of root closure is anticipated. ${ }^{63}$ Despite the difficulties mentioned earlier, mandibular third molar teeth can still erupt in the position of the second molars, but not without deficiencies. A retrospective study by De-la-RosaGay et $a^{62}$ resulted only in $66.2 \%$ of third mandibular molar eruption to its correct position when the ILM2 was extracted. The failure was accounted for by the later Nolla's stages of development, which is the root closure and completion. This finding is crucial along with Gooris and colleagues'58 study, in which the optimal time of ILM2 extraction depends on the adjacent third molar's root development. Such time should be from the crown completion to two-thirds root development. The third molars that failed to erupt successfully either had a severe mesial tilt or the proximal contact was not achieved, thereby requiring more orthodontic correction. ${ }^{62}$

Correct eruption of third mandibular molars has been mentioned as unpredictable and inconsistent. ${ }^{5}$ In terms of arch length, Richardson and Richardson ${ }^{64}$ proposed that one can opt for second mandibular molar extraction if the arch length is deficient, with the certainty that the third molar would be impacted and the proper eruption is assumed. However, Magnusson and Kjellberg ${ }^{26}$ concluded the opposite for this condition, as they advised that the patient should be cautioned that the final position of the third molars in both arches may be unfavorable, leading to more orthodontic problems such as crossbites. Among all the surgical treatment modalities that transpired in their retrospective study, the second molar extraction with emphasis on the mandibular second molars received the most unsatisfactory results. To address these problems, an additional study by De-la-rosa-Gay et al ${ }^{65}$ in 2010 developed a predictive model to estimate the degree of tilting of the eruption of the third molars in both upper and lower teeth by using panoramic radiographs, and by calculating angles and coefficients. The predictive models were successful after several years, except for some mandibular molars mentioned in the study. Although the mandibular results in the study were not as successful as the maxillary results, this can still be an added prognostic value for treatment planning that will involve second molar extractions.

Inconsistencies in some cases are inevitable, so with thorough assessment and treatment planning, eventual ILM2 extractions can be an option. The case Boffano et al presented was extraction by sectioning. In the said case, the ILM2 was deeply impacted, with the third molar situated above it and arranged parallel to each other in a horizontal position. Weighing the risks and benefits is valuable in these kinds of procedures. So, in this particular case, both ILM2s are better to be extracted because of the tediousness of the uprighting procedure and the proximity of the inferior alveolar nerve to the ILM2. Removal of ILM2 was also a preference for Mariano et $\mathrm{al}^{66}$ since the impacted tooth was very deep with distoangular orientation. Both cases have been synthesized to consider crucial factors such as the patient's age, the thickness of the underlying bone in the area, and the location and position of the ILM2. Details can be seen in - Table 7.

Proper case selection for the ILM2 extraction procedure is essential as most of the outcomes presented were

Table 7 Case reports of extracted impacted second molars

\begin{tabular}{|l|l|l|l|l|l|l|l|l|}
\hline Author & Year & $\begin{array}{l}\text { Study } \\
\text { Design }\end{array}$ & $\begin{array}{l}\text { Second } \\
\text { molar }\end{array}$ & Age, gender & Outcomes & Follow-up & $\begin{array}{l}\text { Third } \\
\text { molar } \\
\text { status }\end{array}$ & Remarks \\
\hline Mariano et al $^{66}$ & 2006 & $\begin{array}{l}\text { Case } \\
\text { report }\end{array}$ & $\# 47$ & $\begin{array}{l}26 \text { years old, } \\
\text { female }\end{array}$ & $\begin{array}{l}\text { No pain, } \\
\text { no paresthesia }\end{array}$ & $\begin{array}{l}1 \text { year: bone } \\
\text { healing }\end{array}$ & Retained & $\begin{array}{l}\text { Difficult extraction } \\
\text { with sectioning }\end{array}$ \\
\hline Boffano et al $^{63}$ & 2010 & $\begin{array}{l}\text { Case } \\
\text { report }\end{array}$ & $\# 37$ & $\begin{array}{l}19 \text { years old, } \\
\text { female }\end{array}$ & $\begin{array}{l}\text { No pain, } \\
\text { no paresthesia }\end{array}$ & $\begin{array}{l}6 \text { months: } \\
\text { bone healing } \\
\text { observed }\end{array}$ & Retained & $\begin{array}{l}\text { Difficult extraction } \\
\text { with sectioning }\end{array}$ \\
\hline
\end{tabular}


unpredictable. The clinician must also be careful as one disadvantage is possible supraeruption of the opposing tooth which occurs if the tooth is left without contact from the antagonist for prolonged periods, leading to further challenging orthodontic correction. ${ }^{67}$ To a large extent, the length of time for correction, the proximity to the inferior alveolar canal, the morphological anomalies of the ILM2, and the overall health of the patient have to be considered. More studies are needed, with suggested emphasis on position and classification of the ILM2 and third molars, and their corresponding management, to assist the clinician in the clinical setting if such a need arises.

\section{Autotransplantation}

As early as the 1950s, autotransplantations or transplantations have been proposed as a replacement modality for extracted teeth. It is broadly known as relocating the tooth from its alveolar socket to another area in the same person. ${ }^{68}$ Choosing this treatment option is viable when surgical exposure and orthodontic traction have been unsuccessful. ${ }^{69}$ Autotransplantations are often suggested to have a good prognosis as they preserve function, mastication, and proprioception, particularly in young patients. ${ }^{70}$ It is a feasible option since dental implants are contraindicated for growing patients due to their maturing alveolar arches. ${ }^{71,72}$ Furthermore, orthodontic treatment is more or less unnecessary in this type of modality. ${ }^{73}$

Currently, there are no specific guidelines when it comes to the transplantation of teeth. ${ }^{74,75}$ Many case reports have shown that it is especially beneficial to second mandibular molar space rehabilitation, due to the general claim that transplantations reduce alveolar resorptions. ${ }^{76}$ Moreover, it was attested that this method is less traumatic than performing odontectomy. ${ }^{77}$ It is also important that when doing this technique, the donor and recipient teeth should be morphologically analogous to each other to minimize extraoral time, thus maximizing positive results. ${ }^{13}$

Case selection for third molar transplantation to the ILM2 site is of utmost importance. Similar to uprighting surgical procedures of the ILM2, autotransplantations of the adjacent third molars were believed to require a certain root development stage for successful outcomes. Radiographic measurements of the third molar root length had been used before, disputing that 2 to $3 \mathrm{~mm}$ or 3 to $5 \mathrm{~mm}$ are the optimal lengths for a good transplantation prognosis. ${ }^{78}$ Similar to root development standards in surgical uprighting of ILM2, one-half to three-fourths of root development of the third molar have also been reinforced as an acceptable guideline. ${ }^{13,26,76,79,80}$ However, compelling evidence also demonstrated a high success rate with mature third molars with complete root formation. ${ }^{81-84}$ The actual success rates were established on mature teeth because of atraumatic and swift transplantation methods, sufficient alveolar bone dimensions, and aseptic protocols utilized. Despite the success rates, autotransplantations still entail immense risk like periodontal and pulpal complications after the procedure, specifically for mature teeth. ${ }^{4,5}$

To date, there are only case reports and retrospective studies that showcased transplantation of third molars to their adjacent second molar extraction sites. Most of them were about extracted second molars that were either decayed or with pulpal pathosis and were not extracted due to impaction or uneruption. ${ }^{72,79,81,84-86}$ Regardless, three case reports matched our criteria. The first report is one of Clokie and team's ${ }^{77}$ case series, where impacted lower right third and second molars were evaluated.

The decision to extract the ILM2 was reinforced since orthodontic correction cannot be performed. To rehabilitate the space, they transplanted the impacted lower third molars tooth adjacent to the ILM2 since it has two-thirds root development. Lai, ${ }^{87}$ on the other hand, reported a case where he extracted a left ILM2 with a residual follicle left in the socket. He transplanted the adjacent unerupted third molar with one-fourth root development. Both cases yielded positive results as both teeth proceeded with their root development, and maintained their pulp vitality and function.

Ahmed Asif et $\mathrm{al}^{88}$ reported a transplantation case with bilateral impacted third and second mandibular molars with completely formed roots. The ILM2s were sectioned and replaced with the atraumatically removed third molars under general anesthesia. As expected, the autotransplanted teeth were endodontically treated after splinting, which was related to the previous statement about complications of transplanting mature teeth. The outcome explains that caution should be prompted in such clinical situations, no matter how short the extraoral time and how atraumatic the procedure was performed. The details of these cases are shown in - Table 8.

Three existing case reports in managing ILM2 are not sufficient to draw a significant conclusion. However, we can derive from long-term case studies and retrospective studies that immature third mandibular molars transplanted to second molar recipient sites were more successful in growing patients with good oral hygiene. ${ }^{83,86,89}$

Overall, proper case selection and patient's cooperation are essential to autotransplantations as the outcomes are variable and unpredictable. Many contributing factors can affect the treatment as there is no conclusive evidence and no prevailing guidelines to date. ${ }^{75,90}$ Undoubtedly, the benefits outweigh the risks of performing the transplantation. Constantly reminding the patient about maintaining oral hygiene, attending yearly recalls, and checking the status of the implanted tooth are minor inconveniences but will tremendously help in the success of the treatment.

\section{Third Molar Extractions}

Terry and Hegtvedt ${ }^{12}$ in 1993 stated that mandibular third molars are one of the contributing factors of malpositioned second mandibular molars; therefore, its removal is required. Pogrel ${ }^{35}$ favored the idea as the ease of uprighting can be attained without the presence of the third molar beside the ILM2. He did not extract the third molars in his cases because their proximity does not affect the ILM2 and simply because the third molar buds are invisible radiographically. According to Going and ReyesLois, ${ }^{20}$ the presence of a third molar does not affect the results promised in the surgical uprighting procedure. 
Table 8 Case reports of autotransplantation involving impacted mandibular second molars

\begin{tabular}{|c|c|c|c|c|c|c|c|c|}
\hline Author & Year & Age/gender & $\begin{array}{l}\text { Recipient } \\
\text { site }\end{array}$ & $\begin{array}{l}\text { Donor } \\
\text { tooth }\end{array}$ & $\begin{array}{l}\text { Root } \\
\text { development } \\
\text { of the donor } \\
\text { tooth }\end{array}$ & $\begin{array}{l}\text { Status of } \\
\text { transplanted } \\
\text { tooth }\end{array}$ & Outcomes & Remarks \\
\hline Clokie et al ${ }^{77}$ & 2001 & $\begin{array}{l}\text { 17-year-old, } \\
\text { female }\end{array}$ & $\# 47$ & $\# 48$ & $\begin{array}{l}2 / 3 \text { root } \\
\text { formation }\end{array}$ & Not mentioned & Successful & $\begin{array}{l}\text { Both teeth } \\
\text { were impacted }\end{array}$ \\
\hline Lai ${ }^{87}$ & 2009 & $\begin{array}{l}\text { 14-year-old, } \\
\text { male }\end{array}$ & $\# 37$ & $\# 38$ & $\begin{array}{l}1 / 4 \text { root } \\
\text { formation }\end{array}$ & $\begin{array}{l}3 \text { months of } \\
\text { progressive } \\
\text { root formation } \\
\text { of transplanted } \\
\text { tooth }\end{array}$ & $\begin{array}{l}\text { Tooth in } \\
\text { occlusal level } \\
\text { in } 7 \text { months } \\
\text { with new bone } \\
\text { formation } \\
\text { observed }\end{array}$ & $\begin{array}{l}\text { Recipient } \\
\text { socket was } \\
\text { intended to } \\
\text { still have } \\
\text { residual } \\
\text { follicle from } \\
\text { an extracted } \\
\text { tooth }\end{array}$ \\
\hline Ahmed Asif ${ }^{88}$ & 2017 & $\begin{array}{l}\text { 24-year-old, } \\
\text { female }\end{array}$ & $\# 37, \# 47$ & $\# 38, \# 48$ & $\begin{array}{l}\text { Complete } \\
\text { root } \\
\text { formation }\end{array}$ & $\begin{array}{l}\text { Endodontic } \\
\text { treatment } \\
\text { performed } \\
\text { after splinting }\end{array}$ & $\begin{array}{l}\text { Bone healing } \\
1 \text { year after } \\
\text { completion of } \\
\text { treatment }\end{array}$ & $\begin{array}{l}\text { Second } \\
\text { impacted } \\
\text { molars } \\
\text { removed by } \\
\text { sectioning }\end{array}$ \\
\hline
\end{tabular}

Furthermore, Johnson and Taylor ${ }^{91}$ provided indirect testimony for this claim. The knowledge of the mandibular third molar eruption pattern in this matter comes to play. However, it is observed that either option is not a factor in expediting the treatment time since both options from our case reports achieved uprighting of the tooth within a maximum of 13 months.

Nonetheless, several authors have articulated that mandibular third molar extraction cases are unnecessary for surgical uprighting procedures. ${ }^{18,92,93}$ One reason for unnecessary removal is the presence of a spatial relationship between the third mandibular molars and the second mandibular molars that can aid in the latter's uprighting. ${ }^{94}$ With all things considered, it is up to the clinician whether the extraction of adjacent third molar can simplify the treatment.

\section{Future Directions}

Since only limited studies were found in every scope of surgical uprighting of ILM2, documentation is encouraged with detailed specifics, including the classification and position of the adjacent third molar, root development, and proximity to lingual nerve and inferior alveolar nerve, and other related aspects of ILM2. These details will be helpful in further understanding the etiology of such occurrences. Clearer methodologies can help draw definitive conclusions, consequently setting a standard guideline for managing these anomalies properly. Variation of treatment on bilateral cases is especially helpful, but weighing risk and benefits to such cases is still essential. Specifically, in the case of third lower molar extractions, a bilateral comparison between the retained and extracted third lower molar while uprighting its adjacent second molar on the same patient will be valuable in contributing to the discussion.

Prescribing analgesics is common practice, especially after surgical manipulations involving ILM2. ${ }^{5,20}$ In particular, ibuprofen can be given preoperatively or postoperatively for pain management. ${ }^{16,93}$ Dexamethasone is a corticosteroid used to prevent postoperative pain, trismus, and edema after impacted third molar surgeries, ${ }^{66,71}$ and its effect can be advantageous after ILM2 surgical procedures, specifically with surgical uprighting by luxation, miniplates, sectioning, and autotransplantations. The outcomes can be beneficial, since postoperative complications are anticipated. The possibility of neuropathic and chronic pain can occur in difficult cases, so chronic pain management protocols are also suggested to be given. ${ }^{95}$

The latest trends that can be used efficiently in our particular case of autotransplantation are three-dimensional printed models and CARP (computer-aided rapid prototyping) for creating treatment planning templates. These threedimensional adjuncts are superior to radiographic imaging as they can approximate the morphology of the third mandibular molar to be placed in the socket. Thus, the predictability of the placement is expected in a short time. ${ }^{96-100}$ Simply employing these innovative techniques can add to the diagnostic value and can contribute to the predictability of ILM2.

Bone grafting procedures are also incorporated in mandibular third molar transplantations as a supplementary technique since inadequate buccolingual width and overpreparation of the transplant site may lead to eventual resorption of the alveolar buccal bone, which can yield a poor prognosis. ${ }^{76,81,82}$ Grafting materials like xenografts and autogenous tooth-bone graft can be used on areas with deficient bone, as well as collagen membranes. ${ }^{101,102}$ It is necessary to compare the long-term results of such to determine which bone graft material is preferred in these cases.

Comparison of wound healing materials is another path to be studied pertaining to the aforementioned studies to lessen the postoperative sequelae expected.

Published cases about autotransplantations regarding replacement of second mandibular molars have focused more on the adjacent third molar as the donor tooth. 
However, it will be interesting to see outcomes of the transplanted site from an upper molar as a donor tooth or the contralateral mandibular molar. The results can be furthered as one of the treatment options if the clinician is faced with a situation where the adjacent third molar is not available. This can expand the knowledge domain on autotransplantation as an excellent elective procedure as more options are presented.

Advancements in autotransplantation using piezosurgery have also been used in a third molar to be transplanted into a second molar socket. Atraumatic harvesting of the donor tooth to the recipient site using this device leads to unharmed periodontal ligament fibers that can count for less occurrence of complications. The piezosurgery can also be used for noninvasive socket preparation because of its ability to remove unnecessary bone judiciously. ${ }^{19,79}$ More studies on utilization of this device on ILM2 and third molars are recommended.

Quality-of-life assessments should also be undertaken as most of these procedures are rather invasive. The miniscrews and miniplates located in the retromolar area seem to be uncomfortable to patients during function. Thus, the qualityof-life assessment studies can help the clinician choose which modality the patient will comply with.

Updated studies on surgical techniques regarding ILM2 are required since advanced trends in the orthodontic and surgical fields are evolving. It is also needed for a better understanding of these occurrences. Lastly, the necessity for long-term follow-up studies is also advised to ensure the effectiveness of every modality discussed.

\section{Limitations}

Few case reports and retrospective studies spanning more than 20 years are available regarding the management of impacted second molars. The authors of each study made assumptions that are all substantial in contributing to management and case selection. The points made are sufficient to guide the decision-making process, but robust standards cannot be made. Although most of the findings are not current, the case reports and retrospective studies are still relevant to techniques applied in the modern setting, reinforcing the effectiveness of the surgical modality.

\section{Conclusion}

This review covered the surgical aspects of uprighting, repositioning, and autotransplantation, with novel approaches regarding ILM2. Various works have already documented well-known success rates and prognoses for surgical exposures, surgical uprighting, and transplantation, especially presented by retrospective studies. In addition, surgical approaches regarding ILM2 are less complicated than orthodontic uprighting techniques because they require lesser tools with fewer steps. Hence, these surgical modalities are not time-consuming. All in all, the outcome of surgical intervention depends on case selection, root development of the ILM2, careful surgical manipulation, and adherence to sound biological principles. Patient's compliance, general health, and oral hygiene should also be highlighted. Nevertheless, there is a constant need for other innovative, advanced, and atraumatic surgical approaches for ILM2 to give patients more options to improve compliance and comfort.

Authors' Contributions

\begin{tabular}{|l|l|}
\hline Authors' contributions & Name of authors \\
\hline Conceptualization & D.I.S. \\
\hline Methodology & D.I.S. \\
\hline Validation & D.R. \\
\hline Formal analysis & N.W. \\
\hline Investigation & N.W. \\
\hline Resources & D.R. \\
\hline Writing-original draft preparation & D.I.S. \\
\hline Writing-review and editing & D.R. \\
\hline Visualization & N.W. \\
\hline Supervision & N.W. \\
\hline Project administration & D.R., N.W. \\
\hline Final approval & N.W. \\
\hline Agreed to be accountable & N.W. \\
\hline
\end{tabular}

Funding

None.

Conflict of Interest

None declared.

\section{Acknowledgments}

The authors would like to thank the staff, colleagues, and dental assistants including coworkers in Clinical Science Department of Walailak University International College of Dentistry and Department of Preventive Dentistry, Division of Orthodontics, Faculty of Dentistry Khon Kaen University,Thailand. Finally, the authors would like to thank Christian Estacio and Frances Selvido for the English editing and revising of the manuscript.

\section{References}

1 Alling CC III, Catone GA. Management of impacted teeth. J Oral Maxillofac Surg 1993;51(1, Suppl 1):3-6

2 Shapira Y, Borell G, Nahlieli O, Kuftinec MM, Stom D. Uprighting mesially impacted mandibular permanent second molars. Angle Orthod 1998;68(02):173-178

3 Anderson K, Murtagh K, Sacks HG. Soft tissue and occlusal management in the surgical uprighting of impacted molars: technical note. J Oral Maxillofac Surg 2012;70(08):e438-e440

4 Kravitz ND, Yanosky M, Cope JB, Silloway K, Favagehi M. Surgical uprighting of lower second molars. J Clin Orthod 2016;50(01): $33-40$

5 McAboy CP, Grumet JT, Siegel EB, Iacopino AM. Surgical uprighting and repositioning of severely impacted mandibular second molars. J Am Dent Assoc 2003;134(11):1459-1462

6 Proff P, Bayerlein T, Fanghänel J, Allegrini S Jr, Gedrange T. Morphological and clinical considerations of first and second 
permanent molar eruption disorders. Ann Anat 2006;188(04): 353-361

7 Valmaseda-Castellón E, De-la-Rosa-Gay C, Gay-Escoda C. Eruption disturbances of the first and second permanent molars: results of treatment in 43 cases. Am J Orthod Dentofacial Orthop 1999;116(06):651-658

8 Varpio M, Wellfelt B. Disturbed eruption of the lower second molar: clinical appearance, prevalence, and etiology. ASDC J Dent Child 1988;55(02):114-118

9 Frank CA. Treatment options for impacted teeth. J Am Dent Assoc 2000;131(05):623-632

10 Dessner S. Surgical uprighting of second molars: rationale and technique. Oral Maxillofac Surg Clin North Am 2002;14(02): 201-212

11 Boynton T, Lieblich SE. Surgical uprighting of second molars. Atlas Oral Maxillofac Surg Clin North Am 2013;21(02): 235-237

12 Terry BC, Hegtvedt AK. Self-stabilizing approach to surgical uprighting of the mandibular second molar. Oral Surg Oral Med Oral Pathol 1993;75(06):674-676

13 Tsukiboshi M. Autotransplantation of teeth: requirements for predictable success. Dent Traumatol 2002;18(04):157-180

14 Caminiti MF, El-Rabbany M, Lou T, Reinish EI. Surgical uprighting of mandibular second molars: a single-group retrospective cohort study. Am J Orthod Dentofacial Orthop 2020;158(06): 849-855

15 Lee K-J, Park Y-C, Hwang W-S, Seong E-H. Uprighting mandibular second molars with direct miniscrew anchorage. J Clin Orthod 2007;41(10):627-635

16 Altieri F, Guarnieri R, Mezio M, et al. Uprighting impacted mandibular second molar using a skeletal anchorage: a case report. Dent J (Basel) 2020;8(04):E129

17 Zeitler DL. Management of impacted teeth other than third molars. Oral Maxillofac Surg Clin North Am 1993;5(01): 95-103

18 Padwa BL, Dang RR, Resnick CM. Surgical uprighting is a successful procedure for management of impacted mandibular second molars. J Oral Maxillofac Surg 2017;75(08):1581-1590

19 Nagori SA, Jose A, Bhutia O, Roychoudhury A. Evaluating success of autotransplantation of embedded/impacted third molars harvested using piezosurgery: a pilot study. Acta Odontol Scand 2014;72(08):846-851

20 Going RE Jr, Reyes-Lois DB. Surgical exposure and bracketing technique for uprighting impacted mandibular second molars. J Oral Maxillofac Surg 1999;57(02):209-212

21 Lorente C, Perez-Vela M, Lorente P, Lorente T. Miniscrew-supported pole technique: surgical-orthodontic approach for impacted or retained second molars in adolescents. Int Orthod 2021;19(01):147-158

22 Fan W, Gao D, Wang Y, et al. Three-dimensional measurement and analysis of mandibular characteristics in subjects with impacted mandibular second molars. Orthod Craniofac Res 2020;23(03):332-341

23 Kenrad J, Vedtofte H, Andreasen JO, Kvetny MJ, Kjær I. A retrospective overview of treatment choice and outcome in 126 cases with arrested eruption of mandibular second molars. Clin Oral Investig 2011;15(01):81-87

24 la Monaca G, Cristalli MP, Pranno N, Galluccio G, Annibali S, Pippi R. First and second permanent molars with failed or delayed eruption: clinical and statistical analyses. Am J Orthod Dentofacial Orthop 2019;156(03):355-364

25 Manosudprasit M, Wangsrimongkol T, Pisek P, Chantaramungkorn M. Management of bilateral severely impacted mandibular second molars: a case report. J Med Assoc Thai 2013;96(Suppl 4):S157-S161

26 Magnusson C, Kjellberg H. Impaction and retention of second molars: diagnosis, treatment and outcome. A retrospective follow-up study. Angle Orthod 2009;79(03):422-427
27 Abate A, Cavagnetto D, Fama A, Matarese M, Bellincioni F, Assandri F. Efficacy of operculectomy in the treatment of 145 cases with unerupted second molars: a retrospective casecontrol study. Dent J (Basel) 2020;8(03):E65

28 Sawicka M, Racka-Pilszak B, Rosnowska-Mazurkiewicz A. Uprighting partially impacted permanent second molars. Angle Orthod 2007;77(01):148-154

29 Guo S, Dipietro LA. Factors affecting wound healing. J Dent Res 2010;89(03):219-229

30 Sangha TK, Sangha SK, Hanna B, Tayab T, Padala S. Surgical uprighting of impacted mandibular second molar: a narrative review. J Oral Med Oral Surg. 2021;27(02):1-8

31 Shellhart WC, Oesterle LJ. Uprighting molars without extrusion.J Am Dent Assoc 1999;130(03):381-385

32 Shipper G, Thomadakis G. Bone regeneration after surgical repositioning of impacted mandibular second molars: a case report. Dent Traumatol 2003;19(02):109-114

33 Cho SY, Ki Y, Chu V, Chan J. Impaction of permanent mandibular second molars in ethnic Chinese schoolchildren. J Can Dent Assoc 2008;74(06):521

34 Peskin S, Graber TM. Surgical repitioning of teeth. J Am Dent Assoc 1970;80(06):1320-1326

35 Pogrel MA. The surgical uprighting of mandibular second molars. Am J Orthod Dentofacial Orthop 1995;108(02):180-183

36 Holland DJ. The surgical positioning of unerupted, impacted teeth (surgical orthodontics). Oral Surg Oral Med Oral Pathol 1956;9(02):130-140

37 Fu PS, Wang JC, Wu YM, et al. Impacted mandibular second molars. Angle Orthod 2012;82(04):670-675

38 Johnson TM, Herold RW, Akers JA, DiPirro DA, Berridge JP, McGary RT. Decisions before incisions: technique selection for the distal wedge procedure. Clinic Adv Periodontics 2020;10 (02):94-102

39 Leechanavanichpan P, Rodanant P, Leelarungsun R, Wongsirichat N. Postoperative pain perception and patient's satisfaction after mandibular third molar surgery by primary closure with distal wedge surgery. J Clin Med Res 2019;11(07):489-494

40 Magkavali-Trikka P, Emmanouilidis G, Papadopoulos MA. Mandibular molar uprighting using orthodontic miniscrew implants: a systematic review. Prog Orthod 2018;19(01):1-12

41 Leung MTC, Lee TCK, Rabie ABM, Wong RWK. Use of miniscrews and miniplates in orthodontics. J Oral Maxillofac Surg 2008;66 (07):1461-1466

42 Moon $\mathrm{CH}$. Pros and cons of miniscrews and miniplates for orthodontic treatment. In: Park JH, ed. Temporary Anchorage Devices in Clinical Orthodontics. 2020:731-738

43 Ntolou P, Tagkli A, Pepelassi E. Factors related to the clinical application of orthodontic mini-implants. J Int Oral Health 2018; 10(03):103-110

44 Samrit V, Kharbanda OP, Duggal R, Seith A, Malhotra V. Bone density and miniscrew stability in orthodontic patients. Aust Orthod J 2012;28(02):204-212

45 Chung KR, Kim SH, Kang YG, Nelson G. Orthodontic miniplate with tube as an efficient tool for borderline cases. Am J Orthod Dentofacial Orthop 2011;139(04):551-562

46 Nęcka A, Skrzypczyński J, Antoszewska J. Miniscrew-anchorage in treatment of impacted second molar in mandible - case report. Dent Med Probl 2010;47(03):379-383

47 Giancotti A, Arcuri C, Barlattani A. Treatment of ectopic mandibular second molar with titanium miniscrews. Am J Orthod Dentofacial Orthop 2004;126(01):113-117

48 Giancotti A, Muzzi F, Santini F, Arcuri C. Miniscrew treatment of ectopic mandibular molars. J Clin Orthod 2003;37(07):380-383

49 Mah SJ, Won PJ, Nam JH, Kim EC, Kang YG. Uprighting mesially impacted mandibular molars with 2 miniscrews. Am J Orthod Dentofacial Orthop 2015;148(05):849-861

50 Celebi AA, Gelgor IE, Catalbas B. Correction of mesially impacted lower second molar. J Med Cases 2011;2(31):236-239 
51 Sherwood KH, Burch JG, Thompson WJ. Closing anterior open bites by intruding molars with titanium miniplate anchorage. Am J Orthod Dentofacial Orthop 2002;122(06):593-600

52 Tseng YC, Chen CM, Chang HP. Use of a miniplate for skeletal anchorage in the treatment of a severely impacted mandibular second molar. Br J Oral Maxillofac Surg 2008;46 (05):406-407

53 Miyahira YI, Maltagliati LÁ, Siqueira DF, Romano R. Miniplates as skeletal anchorage for treating mandibular second molar impactions. Am J Orthod Dentofacial Orthop 2008;134(01):145-148

54 Choi BH, Zhu SJ, Kim YH. A clinical evaluation of titanium miniplates as anchors for orthodontic treatment. Am J Orthod Dentofacial Orthop 2005;128(03):382-384

55 Cornelis MA, Scheffler NR, Mahy P, Siciliano S, De Clerck HJ, Tulloch JFC. Modified miniplates for temporary skeletal anchorage in orthodontics: placement and removal surgeries. J Oral Maxillofac Surg 2008;66(07):1439-1445

56 Kuroda S, Sugawara Y, Deguchi T, Kyung HM, Takano-Yamamoto T. Clinical use of miniscrew implants as orthodontic anchorage: success rates and postoperative discomfort. Am J Orthod Dentofacial Orthop 2007;131(01):9-15

57 Sugawara J. Temporary skeletal anchorage devices: the case for miniplates. Am J Orthod Dentofacial Orthop 2014;145(05): 559-565

58 Gooris CG, Artun J, Joondeph DR. Eruption of mandibular third molars after second-molar extractions: a radiographic study. Am J Orthod Dentofacial Orthop 1990;98(02):161-167

59 Orton-Gibbs S, Crow V, Orton HS. Eruption of third permanent molars after the extraction of second permanent molars. Part 1: assessment of third molar position and size. Am J Orthod Dentofacial Orthop 2001;119(03):226-238

60 Russell B, Skvara M, Draper E, Proffit WR, Philips C, White RP Jr. The association between orthodontic treatment with removal of premolars and the angulation of developing mandibular third molars over time. Angle Orthod 2013;83(03):376-380

61 Moffitt AH. Eruption and function of maxillary third molars after extraction of second molars. Angle Orthod 1998;68(02): 147-152

62 De-la-Rosa-Gay C, Valmaseda-Castellón E, Gay-Escoda C. Spontaneous third-molar eruption after second-molar extraction in orthodontic patients. Am J Orthod Dentofacial Orthop 2006;129 (03):337-344

63 Boffano P, Gallesio C, Bianchi F, Roccia F. Surgical extraction of deeply horizontally impacted mandibular second and third molars. J Craniofac Surg 2010;21(02):403-406

64 Richardson ME, Richardson A. Lower third molar development subsequent to second molar extraction. Am J Orthod Dentofacial Orthop 1993;104(06):566-574

65 De-la-Rosa-Gay C, Valmaseda-Castellón E, Gay-Escoda C. Predictive model of third molar eruption after second molar extraction. Am J Orthod Dentofacial Orthop 2010;137(03):346-353

66 Mariano RC, Mariano LdeC, de Melo WM. Deep impacted mandibular second molar: a case report. Quintessence Int 2006;37(10):773-776

67 Compagnon D, Woda A. Supraeruption of the unopposed maxillary first molar. J Prosthet Dent 1991;66(01):29-34

68 Apfel $\mathrm{H}$. Transplantation of the unerupted third molar tooth. Oral Surg Oral Med Oral Pathol 1956;9(01):96-98

69 Arikan F, Nizam N, Sonmez S. 5-year longitudinal study of survival rate and periodontal parameter changes at sites of maxillary canine autotransplantation. J Periodontol 2008;79 (04):595-602

70 Kumar R, Khambete N, Priya E. Successful immediate autotransplantation of tooth with incomplete root formation: case report. Oral Surg Oral Med Oral Pathol Oral Radiol 2013;115(05): e16-e21

71 Huth KC, Nazet M, Paschos E, Linsenmann R, Hickel R, Nolte D. Autotransplantation and surgical uprighting of impacted or retained teeth: a retrospective clinical study and evaluation of patient satisfaction. Acta Odontol Scand 2013;71(06): 1538-1546

72 Mendes RA, Rocha G. Mandibular third molar autotransplantation-literature review with clinical cases. J Can Dent Assoc 2004; 70(11):761-766

73 Turley PK. The management of mesially inclined/impacted mandibular permanent second molars. J World Fed Orthod 2020;9 (3S):S45-S53

74 Plotino G, Abella Sans F, Duggal MS, et al. Clinical procedures and outcome of surgical extrusion, intentional replantation and tooth autotransplantation - a narrative review. Int Endod J 2020;53(12):1636-1652

75 Armstrong L, O'Reilly C, Ahmed B. Autotransplantation of third molars: a literature review and preliminary protocols. Br Dent J 2020;228(04):247-251

76 Thomas S, Turner SR, Sandy JR. Autotransplantation of teeth: is there a role? Br J Orthod 1998;25(04):275-282

77 Clokie CM, Yau DM, Chano L. Autogenous tooth transplantation: an alternative to dental implant placement? J Can Dent Assoc 2001;67(02):92-96

78 Hernandez SL, Cuestas-Carnero R. Autogenic tooth transplantation: a report of ten cases. J Oral Maxillofac Surg 1988;46(12): 1051-1055

79 Bauss O, Zonios I, Rahman A. Root development of immature third molars transplanted to surgically created sockets. J Oral Maxillofac Surg 2008;66(06):1200-1211

80 Kvint S, Lindsten R, Magnusson A, Nilsson P, Bjerklin K. Autotransplantation of teeth in 215 patients. A follow-up study. Angle Orthod 2010;80(03):446-451

81 Mejàre B, Wannfors K, Jansson L. A prospective study on transplantation of third molars with complete root formation. Oral Surg Oral Med Oral Pathol Oral Radiol Endod 2004;97(02): 231-238

82 Yu HJ, Jia P, Lv Z, Qiu LX. Autotransplantation of third molars with completely formed roots into surgically created sockets and fresh extraction sockets: a 10-year comparative study. Int J Oral Maxillofac Surg 2017;46(04):531-538

83 Tang H, Shen Z, Hou M, Wu L. Autotransplantation of mature and immature third molars in 23 Chinese patients: a clinical and radiological follow-up study. BMC Oral Health 2017;17(01):163

84 Bae JH, Choi YH, Cho BH, Kim YK, Kim SG. Autotransplantation of teeth with complete root formation: a case series. J Endod 2010; 36(08):1422-1426

85 Sugai T, Yoshizawa M, Kobayashi T, et al. Clinical study on prognostic factors for autotransplantation of teeth with complete root formation. Int J Oral Maxillofac Surg 2010;39(12): 1193-1203

86 Erdem NF, Gümüșer Z. Retrospective evaluation of immediate impacted third molars autotransplantation after extractions of mandibular first and/or second molars with chronic periapical lesions. J Oral Maxillofac Surg 2021;79(01):37-48

87 Lai FS. Autotransplantation of an unerupted wisdom tooth germ without its follicle immediately after removal of an impacted mandibular second molar: a case report. J Can Dent Assoc 2009; 75(03):205-208

88 Ahmed Asif J, Yusuf Noorani T, Khursheed Alam M. Tooth autotransplantation: an alternative treatment. Bull Tokyo Dent Coll 2017;58(01):41-48

89 Tsukiboshi M, Yamauchi N, Tsukiboshi Y. Long-term outcomes of autotransplantation of teeth: a case series. Dent Traumatol 2019; 35(06):358-367

90 Almpani K, Papageorgiou SN, Papadopoulos MA. Autotransplantation of teeth in humans: a systematic review and metaanalysis. Clin Oral Investig 2015;19(06):1157-1179

91 Johnson E, Taylor RC. A surgical-orthodontic approach in uprighting impacted mandibular second molars. Am J Orthod 1972;61(05):508-514 
92 Wellfelt B, Varpio M. Disturbed eruption of the permanent lower second molar: treatment and results. ASDC J Dent Child 1988;55(03):183-189

93 Cassetta M, Altieri F. The influence of mandibular third molar germectomy on the treatment time of impacted mandibular second molars using brass wire: a prospective clinical pilot study. Int J Oral Maxillofac Surg 2017;46(07):905-911

94 Melsen B, Fiorelli G, Bergamini A. Uprighting of lower molars. J Clin Orthod 1996;30(11):640-645

95 Selvido DI, Bhattarai BP, Rokaya D, Niyomtham N, Wongsirichat N. Pain in oral and maxillofacial surgery and implant dentistry: types and management. Eur J Dent 2021;15(03):588-598

96 Kim E, Jung JY, Cha IH, Kum KY, Lee SJ. Evaluation of the prognosis and causes of failure in 182 cases of autogenous tooth transplantation. Oral Surg Oral Med Oral Pathol Oral Radiol Endod 2005;100(01):112-119

97 Lee S-J, Kim E. Minimizing the extra-oral time in autogeneous tooth transplantation: use of computer-aided rapid prototyping
(CARP) as a duplicate model tooth. Restor Dent Endod 2012;37 (03):136-141

98 Wu Y, Chen J, Xie F, Liu H, Niu G, Zhou L. Autotransplantation of mature impacted tooth to a fresh molar socket using a 3D replica and guided bone regeneration: two years retrospective case series. BMC Oral Health 2019;19(01):248

99 Cross D, El-Angbawi A, McLaughlin P, et al. Developments in autotransplantation of teeth. Surgeon 2013;11(01):49-55

100 Pecci Lloret MP, Martínez EP, Rodríguez Lozano FJ, et al. Influencing factors in autotransplantation of teeth with open apex: a review of the literature. Appl Sci (Basel) 2021;11(09):

101 Jang JH, Lee SJ, Kim E. Autotransplantation of immature third molars using a computer-aided rapid prototyping model: a report of 4 cases. J Endod 2013;39(11):1461-1466

102 Kim Y-K, Choi Y-H. Tooth autotransplantation with autogenous tooth- bone graft: a case report. J Korean Dent Sci 2011;4(02): 79-84 